\title{
Integration of Rare Diseases into Social Services
}

Raquel Castro ${ }^{1 *}$, Dorica Dan ${ }^{2,3,4,5}$

From 7th European Conference on Rare Diseases and Orphan Products (ECRD 2014)

\section{Background}

Social Services are instrumental to the empowerment of people living with rare diseases and to the improvement of their well-being and health. However, these services are still scarce and often not adapted to the needs of people living with rare diseases. Access to these services remains a challenge for patients and families affected by rare diseases.

\section{Objective}

The European Committee of Experts on Rare Diseases Joint Action Work Package 6 - "Specialised Social Services

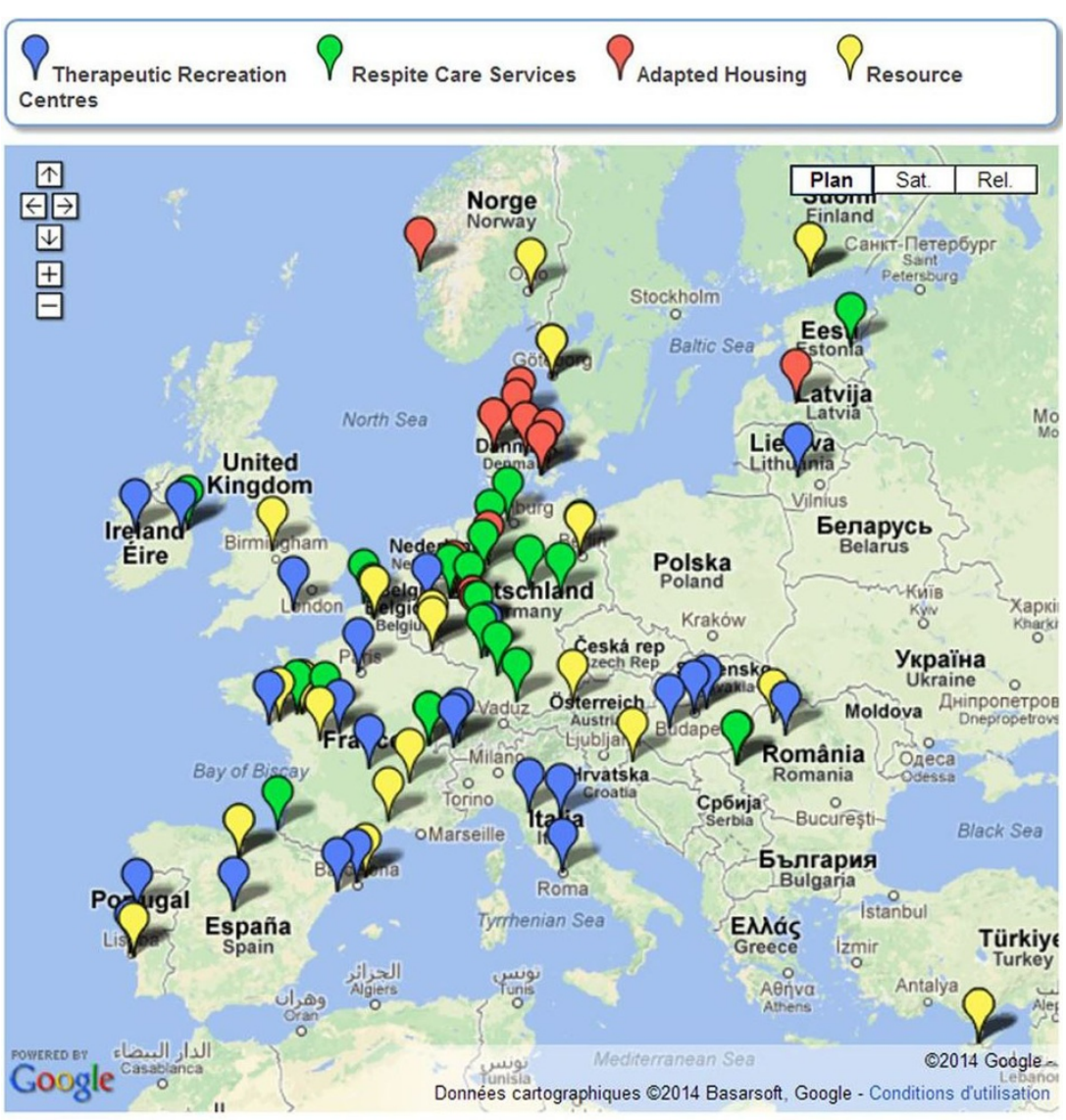

Figure 1 Map of Specialised Social Services.

* Correspondence: raquel.castro@eurordis.org

${ }^{1}$ European Organisation for Rare Diseases - EURORDIS, Paris, France

(c) 2014 Castro and Dan; licensee BioMed Central Ltd. This is an Open Access article distributed under the terms of the Creative Commons Attribution License (http://creativecommons.org/licenses/by/4.0), which permits unrestricted use, distribution, and 
and Integration of RDs into social services and policies" (enabled by EC Co-funding 20112201) - aims at giving more visibility to existing Specialised Social Services and good practices as well as advocating for the integration of people living with rare diseases in services not specific/ exclusive to rare diseases, by working on training of social services providers.

\section{Method}

In order to achieve the objectives above, the following methods have been used: mapping of Specialised Social Services available in Europe via a collection of contacts among members and network; collecting guiding principles for Specialised Social Services and for the Training of social services providers through the organisation multi-stakeholder workshops; compiling case study documents on expert existing services by organising country visits to expert services and applying a detailed questionnaire; advocating for these services via policy fact sheets.

\section{Results}

The following results have been obtained: map of Specialised Social Services (Figure 1) and creation of EURODIS website section; Documents on 'Guiding Principles for Specialised Social Services' and 'Training for Social Services Providers'; Case study documents on Agrenska (Sweden), Frambu (Norway), Bátor Tábor (Hungary) and Group Homes for Prader-Willi Syndrome (Denmark); policy fact sheets on Therapeutic Recreation Programmes, Respite Care Services, Adapted Housing Services, Resource Centres.

\section{Conclusion}

European Committee of Experts on Rare Diseases Join Action Work Package 6 has now made available a set of information on specialised social services and on consensual good practices essential to the improvement of holistic care of people living with rare diseases. As the leader of this Joint Action Work Package, encourages decision-makers, patient representatives, national authorities, patients and families to use these tools to move forward in integrating people living with rare diseases into social services, in coordination with the national plans and strategies for rare diseases.

\section{Authors' details}

${ }^{1}$ European Organisation for Rare Diseases - EURORDIS, Paris, France. ${ }^{2}$ Romanian National Alliance for Rare Diseases, Zalau, Romania. ${ }^{3}$ Romanian Prader-Willi Association, Zalau, Romania. ${ }^{4}$ EURORDIS, Paris, France. ${ }^{5}$ European Commission Expert Group on Rare Diseases â€” DG Health and Consumers, Brussels, Belgium.
Published: 11 November 2014

doi:10.1186/1750-1172-9-S1-P11

Cite this article as: Castro and Dan: Integration of Rare Diseases into

Social Services. Orphanet Journal of Rare Diseases 2014 9(Suppl 1):P11.
Submit your next manuscript to BioMed Central and take full advantage of:

- Convenient online submission

- Thorough peer review

- No space constraints or color figure charges

- Immediate publication on acceptance

- Inclusion in PubMed, CAS, Scopus and Google Scholar

- Research which is freely available for redistribution

Submit your manuscript at www.biomedcentral.com/submit 